\title{
The Monumental Mistake of Evicting Bats from Archaeological Sites-A Reflection from New Delhi
}

\author{
Ravi Umadi ${ }^{1}$, Sumit Dookia ${ }^{2}$ and Jens Rydell ${ }^{3, *}$ \\ 1 Independent Researcher, Basavanagar Road, Kagwad, Karnataka 591223, India; ravisumadi@gmail.com \\ 2 University School of Environment Management, Guru Gobind Singh Indraprastha University, Sector 16 C, \\ Dwarka, Delhi 110078, India; sumitdookia@gmail.com \\ 3 Biology Department, Lund University, 22362 Lund, Sweden \\ * Correspondence: jens.rydell@telia.com; Tel.: +46-705181431
}

Received: 14 January 2019; Accepted: 3 February 2019; Published: 8 February 2019

check for updates

\begin{abstract}
We highlight the importance of an integrated management policy for archaeological monuments and the insect-eating bats that roost inside them. We refer to India, but the issue is general and of worldwide significance. There is increasing evidence that the ecosystem services provided by insect-eating bats in agricultural fields are of vital economic importance, which is likely to increase as chemical pest-control methods become inefficient due to evolving multi-resistance in insects. We visited five archaeological sites in the city of New Delhi. We found bats at all five locations, and three of them harbored large colonies (many thousands) of mouse-tailed bats and tomb bats. These bats likely disperse over extensive areas to feed, including agricultural fields in the vicinity and beyond. All insect-eating bats should be protected and properly managed as a valuable resource at the archaeological sites where they occur. We firmly believe that "fear" of bats can be turned into curiosity by means of education and that their presence should instead enhance the value of the sites. We suggest some means to protect the bats roosting inside the buildings, while mitigating potential conflicts with archaeological and touristic interests.
\end{abstract}

Keywords: agroecology; archaeological conservation; biological control; heritage; ecosystem service; pest control

\section{Introduction}

Effective solutions to environmental issues often require constructive interactions between experts from different scientific disciplines. Indeed, cooperation across subject boundaries may give rise to new ideas, and it is in the interface between subjects that new fields of research may sprout. In this article, we aim to stimulate such interdisciplinary interactions, specifically involving archaeologists, conservation biologists, and perhaps also agricultural scientists. The root of the issue is the potential conflict arising because of the dualism inherent in the human perception of bats; unappreciated, feared, or even hated on one side, but high-profile conservation targets of economic significance on the other. In this note, we call for an integrated management policy for ancient monuments and the bats that live inside them. 
There are several thousand historical temples and monuments in India, mostly administrated by the Archaeological Survey of India [1]. Many of them are currently being restored, and more are likely to undergo restoration efforts, partly to facilitate the development of tourism-a rapidly growing sector in India [2]. The restoration and preservation projects require the consideration of threats from different angles, such as the chemical and biological degradation of the buildings [3], safety issues, the presence of drug abuse, litter, and, last but not least, deliberate destruction and vandalism [4-6]. In this note, we concentrate on the relationship between buildings and bats.

Archaeological sites are essential parts of the cultural heritage of India and the world, but we must not ignore the fact that they also harbor wild animals, notably bats, which are valuable parts of the natural heritage. Buildings and the resident bats should be managed wisely and sustainably for the benefit of both, and bats should not be evicted or eradicated from archaeological sites without earnest consideration. As we shall see, there is increasing evidence that bats are of considerable economic value, because they increase agricultural yields by feeding on pest insects $[7,8]$.

In 1962, bats were reported to be "extremely common" in India, particularly in natural or artificial "caves", including dark corners of old monuments and temples [9-11]. However, things may have changed since 1962, and there is now an urgent need of a comprehensive update of the bat populations in India. Nevertheless, the temples and monuments probably still house many bats, which may remove tons of insects each night over adjacent and distant agricultural fields. Bats are incredibly efficient consumers of flying insects $[12,13]$ and can control and suppress populations of pests $[14,15]$. To find food, some bats, including those considered in this paper, hunt socially [16] and communicate over long distances [17-19], thereby rapidly congregating at rich feeding sites [20,21], for example, where migrations or outbreaks of pest insects occur [22,23].

Little research on this topic has been conducted in India, and indeed, bats remain severely understudied and undervalued in this country. Also, they remain essentially unprotected in India, which is a cause of grave concern in itself. By this note, we attempt to highlight the central role of ancient monuments for the bat populations therein, the pest control function maintained by bats in agriculture, and ultimately, the sustainability of food production in India. We emphasize that the ideas outlined here are based on evidence from other countries. They are speculative with respect to India, only because relevant studies have not been carried out.

\section{The Sites}

During a week in October 2018, we visited five archaeological sites in central New Delhi that still have bat colonies (Table 1). The visits were made in the daytime, with the principal purpose of watching and photographing the resident bats in their natural habitat. 
Table 1. The archaeological sites visited in October 2018 and some basic information about them.

\begin{tabular}{|c|c|c|c|c|c|}
\hline Site & Type of Building & Location & $\begin{array}{c}\text { Time of } \\
\text { Construction }\end{array}$ & $\begin{array}{c}\text { Comments on Renovation, } \\
\text { Lighting, etc. }\end{array}$ & References \\
\hline Agrasen ki Baoli & Stepwell & $\begin{array}{c}\text { Connaught Place, New } \\
\text { Delhi }\end{array}$ & 14th century & None & {$[24,25]$} \\
\hline Feroz Shah Kotla & $\begin{array}{c}\text { Mughal fort, mosque, } \\
\text { stepwell }\end{array}$ & Vikram Nagar, New Delhi & 14th century & $\begin{array}{l}\text { Extensive outdoor lighting, } \\
\text { many visitors, mosque still } \\
\text { used }\end{array}$ & {$[26,27]$} \\
\hline Qutb Minar Complex & $\begin{array}{l}\text { Mughal fort, minar, } \\
\text { mosque }\end{array}$ & Mehrauli, New Delhi & $1192-1316$ and later & $\begin{array}{l}\text { Extensive renovation, many } \\
\text { outdoor lights, intensive } \\
\text { tourism }\end{array}$ & {$[26,28,29]$} \\
\hline Zafar Mahal & Mughal fort & Mehrauli, New Delhi & 18th and 19th centuries & None & {$[26,30]$} \\
\hline Khirki Mosque & Mughal fort, mosque & Malviya Nagar, New Delhi & 14th century & Renovation ongoing & {$[25,31,32]$} \\
\hline
\end{tabular}


One of our sites was the Agrasen ki Baoli, a stepwell, constructed in the 14th century to store rainwater [24]. The other four sites were mosques or forts, constructed under Mughal power during either the Delhi Sultanate (1206-1526) or the subsequent Mughal Empire (1565-1857) [25,26].

The Feroz Shah Kotla fortress mostly consists of ruins but includes Jami Masjid, an old mosque which is still in use [27]. Many vaults and chambers inside the mosque are intact and are frequented by religious people on a large scale on Thursdays for the performance of rituals. [27]. There were several thousand Thursday visitors at the mosque at the time of our first visit, and hundreds of worshippers shared the space inside the vaults and chambers with thousands of bats.

The Qutb Minar complex is also a famous tourist spot and, in fact, the most visited archaeological site in India [28]. It is also a designated UNESCO World Heritage site [29]. The 74-m-high Qutb Minar and the associated archaeological complex include the beautiful Alai Darwaza Gate, the Tomb of Iltutmish, and the Quwwatul Islam, which is the oldest mosque in India, then constructed with reused material from several Brahman temples [29]. The entire complex has recently been thoroughly renovated and extensively fitted with outdoor lights for esthetic and safety purposes. Thereby, it has become quite unfriendly to bats, but some tomb bats still roost in the unlit chambers (Figure 1).

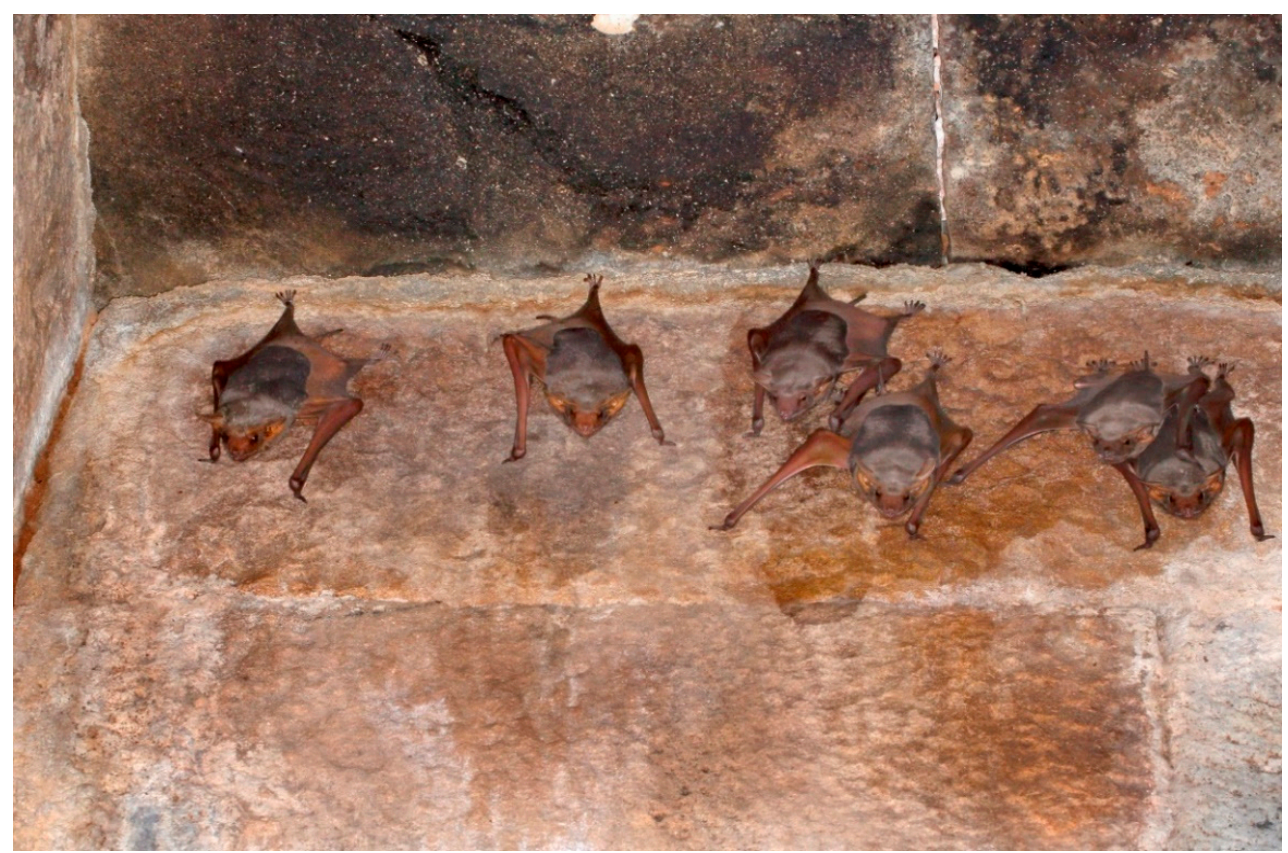

Figure 1. A small group of naked-backed tomb bats (Taphozous nudiventris) in a chamber in Qutb Minar area in New Delhi. Photo by J. Rydell 2018.

The remaining two sites are also open to tourists, but the number of visitors is much lower. The Zafar Mahal monument was built during the 18th and 19th centuries, toward the end of the Mughal Empire [30]. This monument has become entirely enveloped by the surrounding city concrete and traffic over the years. However, there is still room for many bats in several dark chambers and vaults remaining inside (Figure 2). The site is so far untouched by recent renovation attempts, and there are no esthetic lights installed in the premises. However, urban lighting is prevalent in the surroundings. 
Finally, the Khirki Mosque, one of the most important Mughal monuments [31,32], has also become encroached by the growing city, but, fortunately, there are no lights installed in the fort. It harbors many bats of at least four different species, most of them roosting in the dark chambers at ground level, which can be accessed from the outside (Figure 3). Renovation work is ongoing, and it seems likely that it will affect the colony of fruit bats that reside in the main part of the mosque, but hopefully, the chambers at the ground level, where most of the insectivorous bats live, will escape this fate.

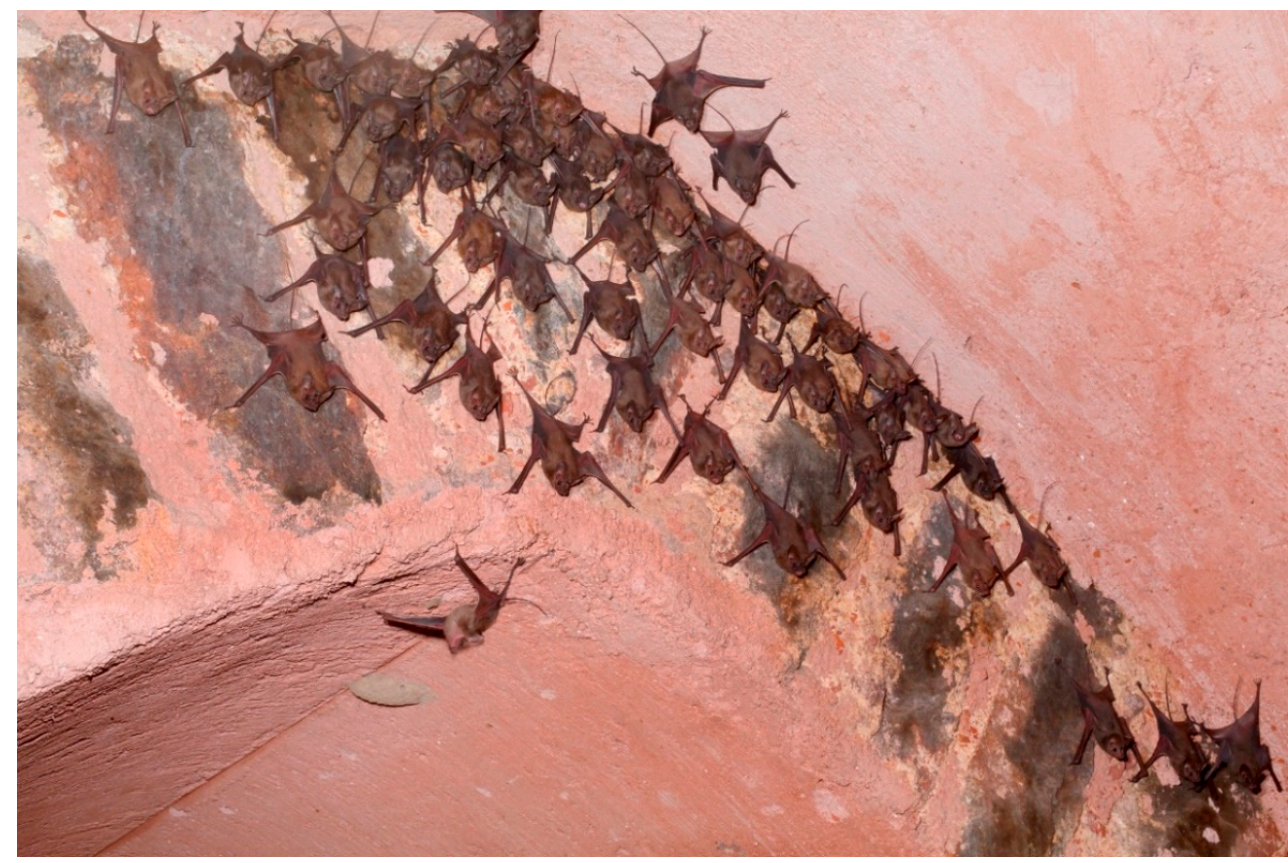

Figure 2. A group of lesser mouse-tailed bats (Rhinopoma hardwickii) in Zafar Mahal in New Delhi. Photo by J. Rydell 2018.

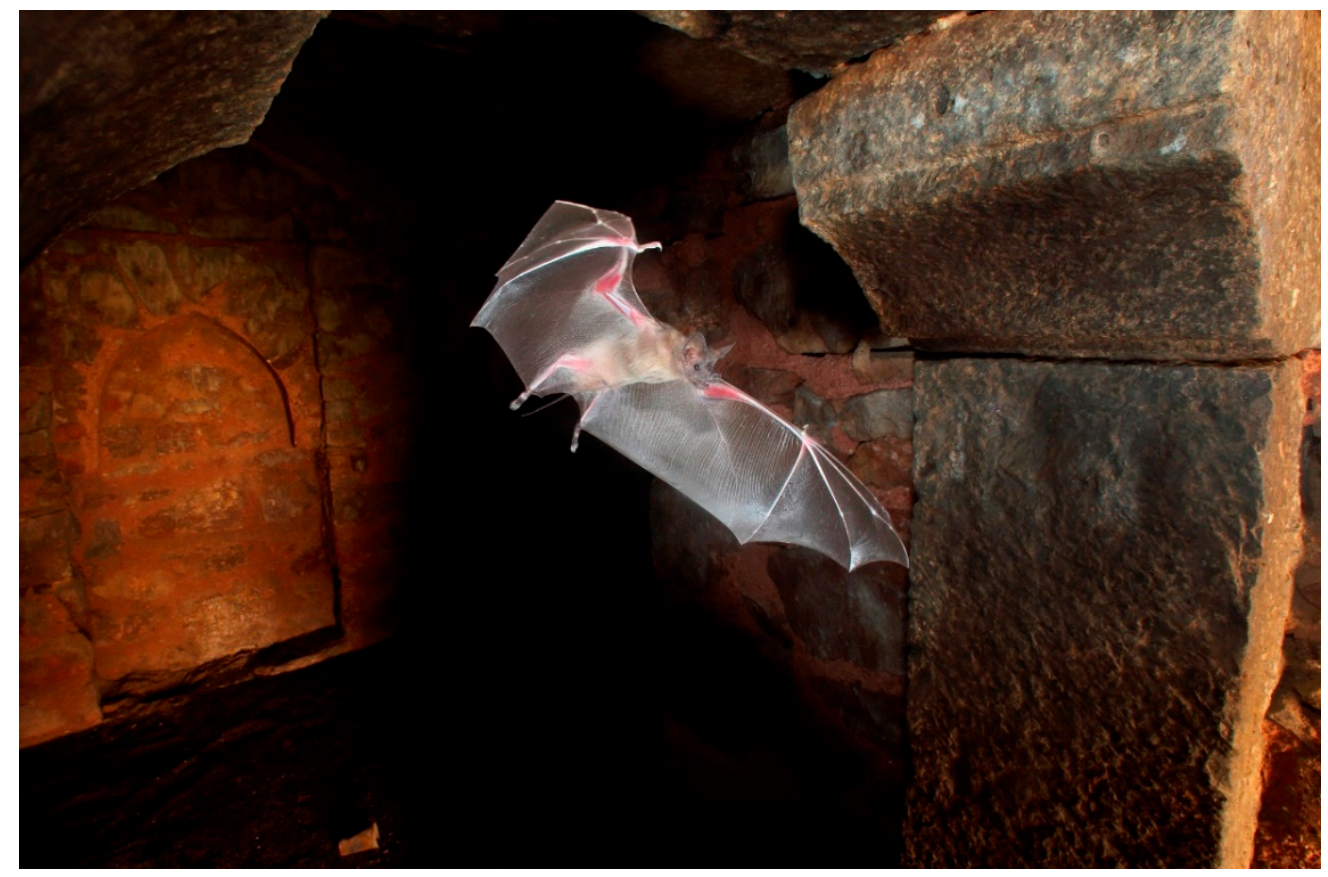

Figure 3. A greater mouse-tailed bat (Rhinopoma microphyllum) in a dark chamber in the Khirki Mosque, New Delhi. Photo by J. Rydell 2018. 
A common factor which made these forts attractive to bats is the presence of several dark and undisturbed vaults or chambers. Smaller groups of bats are usually less selective and were also found in more exposed sites. Darkness is an essential habitat feature for bats, particularly at the roost, because it is their principal protection against predation [33]. Proximity to good feeding sites is another important feature of a good bat roost. Although the forts are all located in urban settings, this has not always been the case, and the distances to the nearest agricultural fields, where the bats may feed, are no more than $2-5 \mathrm{~km}$, a distance that they cover each night easily.

The mouse-tailed bats roosting in the vaults of Feroz Shah Kotla mosque showed a surprising tolerance to visitors even at close range, at least as long as they were ignored by the crowd. This suggests that the bats are seldom harassed in this place. Indeed, it was quite clear that they were tolerated by the crowd and considered as a natural feature of the place. In contrast, the bats reacted defensively to our torches and cameras, a situation they were not accustomed to (Figure 4).

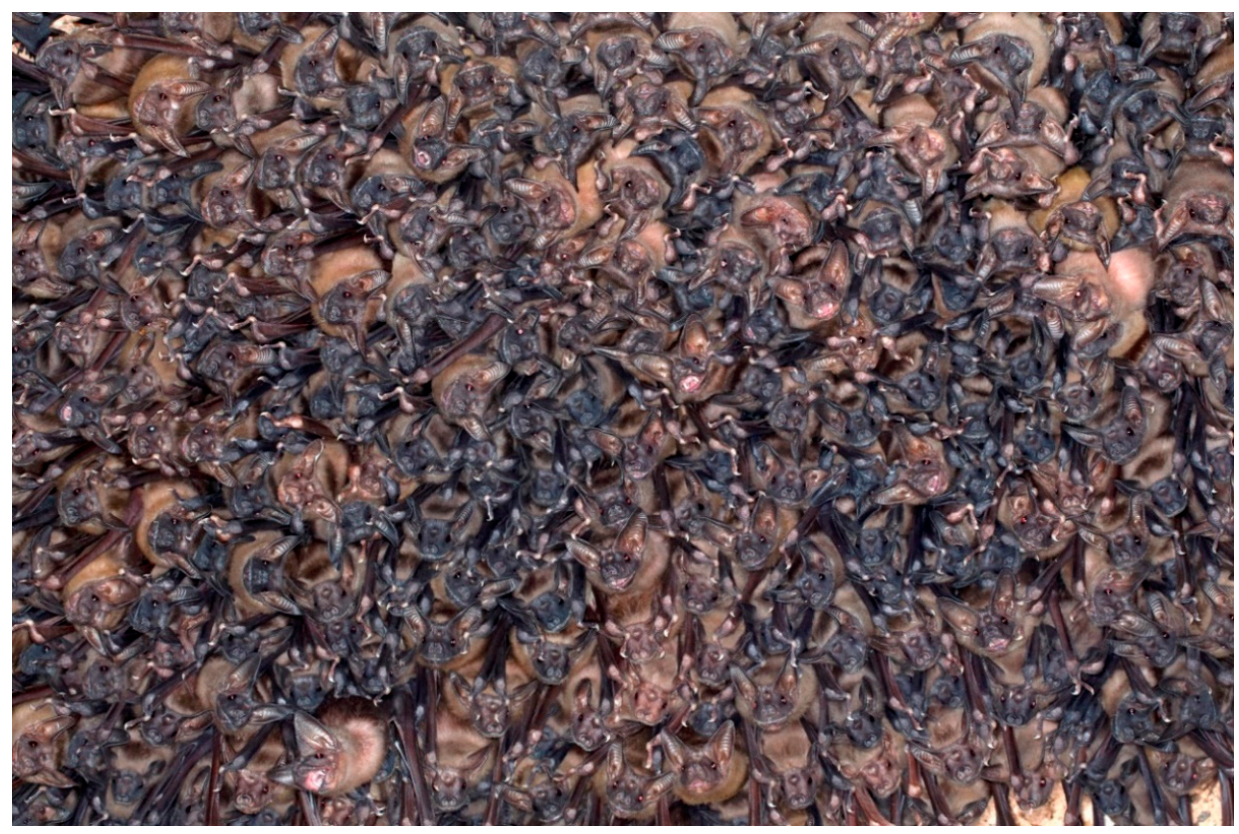

Figure 4. Part of a colony of greater mouse-tailed bats (R. microphyllum) in the Feroz Shah Kotla mosque in New Delhi. The tight clustering is a defensive behavior in response to our disturbance with torch and camera. Interestingly, the bats never responded in this way to the crowd of worshippers just a meter or two away. Photo by J. Rydell 2018.

\section{The Bats}

Bats were found in all the visited sites, although their numbers varied, depending on the availability of undisturbed dark spaces for roosting. At each site, we did a quick survey to record the species present and obtain a rough idea of their numbers (Table 2). 
Table 2. The sites visited and the bat species observed during a one-week field trip to some New Delhi monuments in October 2018.

\begin{tabular}{|c|c|c|c|c|}
\hline \multirow{2}{*}{$\begin{array}{c}\text { Site } \\
\text { Agrasen Ki Baoli }\end{array}$} & \multirow{2}{*}{$\begin{array}{c}\text { Estimated no. of Bats } \\
10,000+\end{array}$} & \multicolumn{2}{|c|}{ Species } & \multirow{2}{*}{$\begin{array}{l}\text { Roosting Location } \\
\text { High in the ceiling }\end{array}$} \\
\hline & & Fruit bats & Rousettus leschenaulti & \\
\hline Zafar Mahul & $\begin{array}{l}1000+ \\
100+\end{array}$ & $\begin{array}{l}\text { Mouse-tailed bats } \\
\text { Tomb bats }\end{array}$ & $\begin{array}{l}\text { Rhinopoma spp. } \\
\text { T. nudiventris }\end{array}$ & $\begin{array}{l}\text { In dark vaults } \\
\text { Small groups in } \\
\text { vaults }\end{array}$ \\
\hline $\begin{array}{l}\text { Feroz Shah Kotla } \\
\text { Mosque }\end{array}$ & $\begin{array}{c}10,000+ \\
100+\end{array}$ & $\begin{array}{l}\text { Mouse-tailed bats } \\
\text { Tomb bats }\end{array}$ & $\begin{array}{l}\text { Rhinopoma spp. } \\
\text { T. nudiventris }\end{array}$ & $\begin{array}{l}\text { In dark vaults } \\
\text { Small groups in } \\
\text { vaults }\end{array}$ \\
\hline Khirki Mosque & $\begin{array}{c}1000+ \\
10,000+ \\
10+\end{array}$ & $\begin{array}{c}\text { Fruit bats } \\
\text { Mouse-tailed bats } \\
\text { Tomb bats }\end{array}$ & $\begin{array}{l}\text { R. leschenaulti } \\
\text { Rhinopoma spp. } \\
\text { T. nudiventris }\end{array}$ & $\begin{array}{l}\text { In the ceiling } \\
\text { In dark vaults } \\
\text { Small groups in } \\
\text { vaults }\end{array}$ \\
\hline Qutb Minar Complex & $100+$ & Tomb bats & T. nudiventris & $\begin{array}{l}\text { Small groups in } \\
\text { vaults, a bigger group } \\
\text { in the tower }\end{array}$ \\
\hline
\end{tabular}

Although there were many individual bats at the sites, they belonged to no more than four species (Table 2), which is just a tiny fraction of the over 100 bat species known from the Indian subcontinent [34]. The sample represents species that are relatively tolerant to the presence of people and perhaps other forms of disturbance. The mouse-tailed bats, of which we found two species, the greater Rhinopoma microphyllum and the lesser Rhinopoma hardwickii, live either in small groups in relatively exposed corners or in big groups (several thousand individuals) in dark vaults outside the main tourist areas. These bats were by far the most numerous. The larger naked-backed tomb bats (Taphozous nudiventris) typically roosted in small groups in cracks and relatively exposed positions on the walls and ceilings in vaults and rooms. There was also a relatively big colony of what we think was this species, emerging from a high position (ca. 40-50 m) on the Qutb Minar in the evening.

In Table 2 we provide rough estimates of the number of individuals of each species that we observed. The three insectivorous species are all specialized for a nocturnal life in the free aerospace, where they are seldom seen from the ground. The mouse-tailed bats have somewhat short and blunt wings and are weak but persistent fliers [9]. They usually feed at high altitude and $10 \mathrm{~km}$ or more from the roost [16]. In contrast, the tomb bats have longer and narrower wings, which facilitate faster and straighter flight, and they probably fly much further [35]. Although they find their insect food using echolocation, just as most other bats, they use vision to navigate over long distances [36].

Two of the sites that we visited also harbored big colonies of fruit bats, Rousettus leschenaulti, (Table 2). Fruit bats are important as seed dispersers and pollinators of fruiting trees and offer a host of ecological services [37] but they sometimes raise concern in tourist sites because of their noisy presence and odorous excretions. However, in this paper, we will not discuss the fruit bats any further. It is the insect-eating bats that are the focus of this note.

\section{Insect Pests of Rice}

Rice (Oryza sativa) is by far the most important crop in Asia and the world, and we will use it as an illustrative example. However, the pest situation is comparable for all major crops in India, including wheat (Triticum aestivum), cotton (Gossypium hirsutum), soybean (Glycine max), potatoes (Solanum tuberosum), sugarcane (Zaccharum officinarum), and maize (Zea mays) [38]. 
Pest outbreaks are a significant constraint on rice production in India and elsewhere $[39,40]$. The industrial pesticide production and application on cash crops in India is poorly regulated [41], and, at the same time, the use of chemical pesticides in agriculture has dramatically increased over the last decades [42]. The adverse effects of pesticide usage in food crops have been well documented [43], and it is evident that such methods of pest control are unsustainable [44]. In place of chemical pest control agents, other, mostly biological, means are currently being developed, such as mating disruption by use of pheromones or sterile males [45,46]. However, such biological agents represent only a minor proportion of the options available on the market at present [47]. In light of this, the viability of natural pest control agents, such as bats [48,49], will become more and more critical as multi-resistant pests evolve, and chemical control becomes increasingly inefficient.

The economic value of the ecosystem service rendered by bats by feeding on pest insects has never been estimated with respect to India. However, there is growing evidence from other parts of the world, including southern USA [50,51], Southeast Asia [52], the Mediterranean [53], China [54], and Madagascar [55], that bats are major consumers of pest insects with a potential or proven capacity to reduce or control their populations. The sustainability aspect of rice cultivation and food security directly attributable to the conservation of bats is already evident in Southeast Asia [56]. It is noteworthy that such studies make financial projections that closely follow the current economic trends and, hence, should serve as a basis for the economics of conservation policies.

There are about 20 species of insects regarded as major pests of rice in India (Table 3). The adult stages of most of them are active at night or dusk and dawn, and this is usually also the time when their migratory flights take place [57]. This means that the pests are potential food for bats, which are active and search for food at the same time of the day. Indeed, some of the pests, including the most problematic of them all, the brown planthopper (Nilaparvata lugens) and the white-backed planthopper (Sogatella furcifer) are the most important food sources for insectivorous bats feeding over paddy fields in Thailand $[58,59]$ and presumably elsewhere as well. 
Table 3. Some of the most important pests of rice in India and notes on the life habits of the adult stage. The species list is partly adopted from reference [60]. Species marked * are known to be consumed extensively by bats in Thailand (wrinkle-lipped free-tailed bat, Chaerephon plicatus [52,59]).

\begin{tabular}{|c|c|c|c|c|}
\hline \multicolumn{2}{|c|}{ Major Insect Pests of Rice in India } & \multirow{2}{*}{$\begin{array}{c}\text { Migratory Outbreak Species } \\
\text { Yes }^{*}\end{array}$} & \multirow{2}{*}{$\begin{array}{c}\text { Flies at Night } \\
\text { Yes }\end{array}$} & \multirow{2}{*}{$\begin{array}{c}\text { Reference } \\
{[58,61]}\end{array}$} \\
\hline Hemiptera & Brown planthopper (Nilaparvata lugens) & & & \\
\hline & White-backed planthopper (Sogatella furcifer) & Yes* & Yes & [62] \\
\hline & Green leafhopper (Nephotettix virescens) & & Yes & [63] \\
\hline & Green leafhopper (Nephotettix nigropictus) & & Yes & [62] \\
\hline & Zigzag leafhopper (Recilia dorsalis) & & Yes & [64] \\
\hline & Mealy bug (Brevennia rehi) & No & $\mathrm{No}(?)$ & [64] \\
\hline \multirow[t]{2}{*}{ Orthoptera } & Rice grasshopper (Hieroglyphus banian) & Yes & No & [65] \\
\hline & Mole cricket (Gryllus orientalis) & No & Yes & [64] \\
\hline Diptera & Rice gall midge (Orseolia oryzae) & & Yes & [66] \\
\hline \multirow[t]{7}{*}{ Lepidoptera } & Yellow stem borer (Scirpophaga incertulas) & & Yes & [67] \\
\hline & Dark-headed stem borer (Chilo polychrysus) & & Yes & [68] \\
\hline & Striped stem borer (Chilo suppressalis) & & Yes & [62] \\
\hline & Pink stem borer (Sesamia inferens) & & Yes & [65] \\
\hline & Rice leaf folder (Cnaphalocrocis medinalis) & Yes & Yes & [69] \\
\hline & Armyworm (Spodoptera mauritia) & Yes & Yes & [70] \\
\hline & Rice caseworm (Nymphula depunctalis) & & Yes & [65] \\
\hline Coleoptera & Rice hispa (Dicladispa armigera) & Yes & Yes & [64] \\
\hline
\end{tabular}




\section{Discussion}

Will it be practically possible to conserve and manage the tourists and the old buildings as well as the bats therein in a sustainable and non-destructive way? We certainly think so and, indeed, we believe that the bats themselves may even enhance the touristic quality and excitement [71,72]. For example, an evening exodus of thousands of bats from an old monument is a spectacular sight, which probably would be appreciated by many visitors [73], particularly if the show is combined with high-quality information about the ecological importance of the building and the bats. And what could be a better setting for an evening lecture or a public bat-watch excursion than an Indian 14th century Mughal monument?

The presence of many bats residing in old buildings sometimes raises concern because of known or suspected weathering effects on the buildings. Degradation and staining of monuments due to bat excretions certainly occur, but serious weathering effects are unusual and depend critically on the chemical composition of the building material and the excretions [74,75]. Decaying bat guano is usually acidic [76] and therefore affects some limestones and sandstones [74]. However, Indian monuments and temples are constructed from many different materials, depending on the local geology and, although most rocks may be stained, they are not degraded by bat guano or urine [75]. It is essential that the eviction of bats be restricted to cases where it is considered absolutely necessary to prevent irreversible damage, on the basis of authentic scientific information [77].

Large accumulations of bat guano and urine from bats sometimes have a strong smell, and this could indeed repel visitors from compartments used by bats. More seriously, however, dry accumulations of feces can lead to allergic reactions [78] or histoplasmosis [79] infections in humans, particularly if the infected air is inhaled frequently. Hence, it may be wise to remove accumulated bat feces (while using a breathing mask) now and then from spots frequented by tourists, to minimize the smell and the health risk. For the protection of tourists and bats, visitors should be discouraged from entering poorly ventilated compartments with large bat colonies (thousands of bats) and accumulations of feces. If necessary, such compartments can be gated to give bats free passage in and out, while stopping humans from entering. How such bat gates should be designed and constructed is critically important and is described in [80]. Gating could be a suitable measure at some of the ground level compartments of the Khirki mosque, for example (Figure 3).

There is a rich folklore about bats in India, just as in Europe and elsewhere [81], generally depicting bats in a bad light, and this often results in a "fear" of bats [82]. However, in contrast to Europe, there is usually no religious mandate to persecute bats in India, where particularly the Hindu philosophy rather emphasizes the value of life in harmony with nature [83]. In the Feroz Shah Kotla, we observed what seemed to be a tight but peaceful coexistence of bats and humans, mainly Muslims in this case, which must have persisted for a very long time, perhaps for centuries. We do not believe that the average tourist, whether Indian or European, is afraid of bats in the strict sense, but it is very important that this sensitive issue is handled with due respect [82]. European bats, including those in churches and houses, are now seen in a much more positive light than they were just a decade or two ago, thanks to education and enlightenment activities in combination with legal protection. In the case of bats, "fear" is partly an expression of curiosity and fascination, which can be turned into excitement by means of education, perhaps through cooperation with bat scientists. In our view, graffiti and other signs of vandalism [4,5], in combination with an accumulation of plastic bags and other garbage [6] in and around the buildings, almost certainly affect the appeal of the place. Signaling neglect and poor management, the piles of rubbish probably have a much stronger repelling effect on tourists than the presence of bats.

There are very few studies where the fates of bat colonies have been monitored at archaeological sites, following renovations and light installations. However, a recently published long-term (30 years) study of bat colonies (brown long-eared bats, Plecotus auritus) in 115 historical churches in Sweden [84] shows that major renovation work may cause the disappearance of bats, but more likely they will be back when conditions return to normal after the renovation. More importantly, the installation of 
esthetic and/or safety lights, usually done simultaneously with the renovations, is a more serious problem, particularly if the bats' roost and emergence sites become illuminated. In such cases, the bats usually disappear slowly but permanently, most likely because of starvation [85]. Hence, while renovation work is not necessarily harmful to resident bats in the long run if done with care, the installation of lights often has a catastrophic effect on the bat population.

Reported cases of declining populations of wrinkle-lipped free-tailed bats (Chaerephon plicatus) roosting in Buddhist temple caves in Cambodia are quite alarming, although the reason behind the decline remains unknown [86]. One possible explanation is that the use of pesticides in rice fields, where the bats feed, has affected their reproduction and survival over a long time. Bats eat a lot and often live for decades and, if the prey on insects containing pesticides, they may accumulate dangerous concentrations of such chemicals [87]. The scenario predicted by this hypothesis is worrying indeed, as it probably means a severe decline in the ecosystem service now provided by bats.

\section{Conclusions}

There is a long line of reasoning between the management of old monuments in Delhi for the facilitation of tourism, the welfare of the roosting bats therein, and their presumed pest control service over the surrounding agricultural fields. Bats are living components of old monuments, where they may have roosted for centuries, and should be treated as such whenever possible. The ecosystem service they provide by feeding on agricultural pests is considerable (worth 3.7 billion dollars annually in the USA [7]; no figure exists for India). In comparison, the budget for the Archaeological Survey of India for 2018 was 140 million dollars [1,2], which is only a small fraction of the presumed value of the bats. Darkness is the bats' principal protection against predators [88]. We emphasize that lights must be used restrictively and with great care [89]. Clearly, the pivotal role of old monuments harboring bats in tourism, sustainable farming, food safety, and the economic well-being of the society cannot be ignored considering the evidence at hand.

Author Contributions: Conceptualization and field observations: All authors; first draft: J.R.; reviewing, editing, and approval: All authors.

Funding: We had no external funding for this project. However, we acknowledge the Ekman Foundations for general support of studies on the environmental effects of light pollution (to J.R.).

Acknowledgments: We appreciate the help of Rajlakshmi Jha for the information about roosting sites of bats in Delhi monuments and of Johan Eklöf for advice and comments on the manuscript. R.U. extends his gratitude to Subhas and Geeta Umadi for tolerance and support, and to Kiko for moral support during the preparation of this manuscript.

Conflicts of Interest: The authors declare no conflict of interest.

\section{References}

1. Archaeological Survey of India. Available online: http:/ / asi.nic.in/about-us/ (accessed on 31 December 2018).

2. Government of India. India Tourism Statistics at a Glance 2018. Available online: http:/ / tourism.gov.in/ sites/default/files/Other/ITS_Glance_2018_Eng_Version_for_Mail.pdf (accessed on 26 January 2019).

3. Anonymous. Revenue Generated through Entry Fee for Ticketed Monuments of ASI Trebles in Three Years. Available online: https://www.business-standard.com/article/news-cm/revenue-generatedthrough-entry-fee-for-ticketed-monuments-of-asi-trebles-in-three-years-118121800761_1.html (accessed on 26 January 2019).

4. Verma, R. 13 More Monuments May Be Ticketed to Stop Vandals. Available online: https://timesofindia. indiatimes.com/city/delhi/13-more-monuments-may-be-ticketed-to-stop-vandals/articleshow /7892253.cms (accessed on 24 January 2019).

5. Divya, A. Amid Encroachments and Vandalism, 18th Century Zafar Mahal in Sorry State. Available online: https://indianexpress.com/article/cities/delhi/amid-encroachments-and-vandalism-18th-centuryzafar-mahal-in-sorry-state-2767644/ (accessed on 24 January 2019). 
6. Anonymous. Running Short of Attendants, Protected Monuments in City Fall Prey to Vandals. Available online: https://indianexpress.com/article/cities / delhi/running-short-of-attendants-protectedmonuments-in-city-fall-prey-to-vandals / (accessed on 24 January 2019).

7. Boyles, J.G.; Cryan, P.M.; McCracken, G.F.; Kunz, T.H. Economic importance of bats in agriculture. Science 2011, 332, 41-42. [CrossRef] [PubMed]

8. Maas, B.; Cough, Y.; Tscharntke, T. Bats and birds increase crop yield in tropical agroforestry landscapes. Ecol. Lett. 2013, 16, 1480-1487. [CrossRef] [PubMed]

9. Brosset, A. The bats of Central and Western India part I. J. Bombay Nat. Hist. Soc. 1962, 59, $2-61$.

10. Brosset, A. The bats of Central and Western India part II. J. Bombay Nat. Hist. Soc. 1962, 59, 583-625.

11. Brosset, A. The bats of Central and Western India part III. J. Bombay Nat. Hist. Soc. 1962, 59, 707-746.

12. Anonymous. Bats can pack a punch in pest control. Calif. Agric. 1998, 52, 6-7. Available online: http: / / calag.ucanr.edu/Archive/ ?article=ca.v052n01p6b (accessed on 31 December 2018).

13. Buckhurst, A.S. Moths destroyed by a long eared bat. Entomologist 1930, 63, 238.

14. Maine, J.J.; Boyles, J.G. Bats initiate vital agroecological interactions in corn. Proc. Natl. Acad. Sci. USA 2015, 112, 12438-12443. [CrossRef] [PubMed]

15. Maas, B.; Karp, D.S.; Bumrungsri, S.; Darras, K.; Gonthier, D.; Huang, J.C.-C.; Lindell, C.A.; Maine, J.J.; Mestre, L.; Michel, N.L.; et al. Bird and bat predation services in tropical forests and agroforestry landscapes. Biol. Rev. 2016, 91, 1081-1101.

16. Egbert-Berg, K.; Hurme, E.R.; Greif, S.; Goldsthein, A.; Harten, L.; Herrera, M.L.G.; Flores-Martinez, J.J.; Valdés, A.T.; Johnston, D.S.; Eitan, O.; et al. Resource ephemerality drives social foraging in bats. Curr. Biol. 2018, 28, 3667-3673. [CrossRef] [PubMed]

17. Barclay, R.M.R. Interindividual use of echolocation calls: Eavesdropping by bats. Behav. Ecol. Sociobiol. 1982, 10, 271-275. [CrossRef]

18. Gilliam, E.H. Eavesdropping by bats on the feeding buzzes of conspecifics. Can. J. Zool. 2007, 85, 795-801. [CrossRef]

19. Cvikel, N.; Egbert-Berg, K.; Levin, E.; Hurme, E.; Borissov, I.; Boonman, A.; Amichai, E.; Yovel, Y. Bats aggregate to improve prey search but might be impaired when their density becomes too high. Curr. Biol. 2015, 25, 206-211. [CrossRef] [PubMed]

20. Fenton, M.B.; Morris, G.K. Opportunistic feeding by desert bats (Myotis spp.). Can. J. Zool. 1976, 54, 526-530. [CrossRef]

21. Freeman Long, R.; Simpson, T.; Ding, T.-S.; Heydon, S.; Reiul, W. Bats feed on crop pests in Sacramento Valley. Calif. Agric. 1998, 52, 8-10. [CrossRef]

22. McCracken, G.F.; Westbrook, J.K.; Eldridge, M.; Federico, P.; Kunz, T.H. Bats track and exploit changes in insect pest populations. PLoS ONE 2012, 7, e43839. [CrossRef] [PubMed]

23. Krauel, J.J.; Ratcliffe, J.M.; Westbrook, J.K.; McCracken, G.F. Brazilian free-tailed bats (Tadarida brasiliensis) adjust foraging behaviour in response to migratory moths. Can. J. Zool. 2018, 96, 513-520. [CrossRef]

24. Anonymous. Agrasen ki Baoli. Available online: https://en.wikipedia.org/wiki/Agrasen_ki_Baoli (accessed on 26 January 2019).

25. Mittal, J.P. History of Ancient India: From 4250 BC to 637 AD; Atlantic Publishers and Distributors: New Delhi, India, 2014; p. 320. ISBN 978-81-269-0616-1.

26. Schimmel, A. The Empire of the Great Mughals; Reaktion Books: London, UK, 2004; p. 352.

27. Anonymous. Feroz Shah Kotla. Available online: https://en.wikipedia.org/wiki/Feroz_Shah_Kotla (accessed on 4 January 2019).

28. Anonymous. Qutb Minar Complex. Available online: https://en.wikipedia.org/wiki/Qutb_Minar_complex (accessed on 4 January 2019).

29. UNESCO World Heritage Sites. Available online: https://whc.unesco.org/en/list/233 (accessed on 31 December 2018).

30. Smith, R.V. The Delhi That No-One Knows, Zafar Mahal and Sardgha; Orient Blackswan: Hyderabad, India, 2005; pp. 11-15.

31. Welch, A.; Crane, H. The Tughluqs: Master builders of the Delhi Sultanate. Muqarnas (Brill) 1983, 1, $123-166$. [CrossRef]

32. Peck, L. Delhi-A Thousand Years of Building; Roli Books: New Delhi, India, 2005; p. 328. 
33. Kunz, T.H. Roosting ecology of bats. In Ecology of Bats; Kunz, T.H., Ed.; Springer: Boston, MA, USA, 1982; pp. 1-55.

34. Bates, P.J.J.; Harrison, D.L. Bats of the Indian Subcontinent; Harrison Zoological Museum: Sevenoaks, UK, 1997; p. 258.

35. Roeleke, M.; Bumrungsri, S.; Voigt, C.C. Bats probe the aerosphere during landscape-guided altitudinal flights. Mammal Rev. 2018, 48, 7-11. [CrossRef]

36. Boonman, A.; Bar-On, Y.; Cvickel, N.; Yovel, Y. It's not black or white-on the range of vision and echolocation in echolocating bats. Front. Physiol. 2013, 11, 248. [CrossRef]

37. Kunz, T.H.; Braun de Torrez, E.; Bauer, D.; Lobova, T.; Fleming, T.H. Ecosystem services provided by bats. Ann. N.Y. Acad. Sci. 2011, 1223, 1-38. [CrossRef] [PubMed]

38. Oerke, E.C. Crop losses to pests. J. Agric. Sci. 2005, 144, 31. [CrossRef]

39. Oerke, E.C. Crop Production and Crop Protection: Estimated Losses in Major Food and Cash Crops; Elsevier: Amsterdam, The Netherlands, 1994; p. 808.

40. Food and Agricultural Organization of the United Nations. Rice Market Monitor; FAO: Rome, Italy, 2015; Volume 18, pp. 1-6.

41. Abhilash, P.C.; Singh, N. Pesticide use and application: An Indian scenario. J. Hazard. Mater. 2009, 165, 1-12. [CrossRef] [PubMed]

42. Gupta, P. Pesticide exposure-Indian scene. Toxicology 2004, 198, 83-90. [CrossRef] [PubMed]

43. Pimentel, D.; Acquay, H.; Biltonen, M.; Rice, P.; Silva, M.; Nelson, J.; Lipner, V.; Giordano, S.; Horowitz, A.; D'Amore, M. Environmental and economic costs of pesticide use. Bioscience 1992, 42, 750-760. [CrossRef]

44. Jeyaratnam, J. Acute pesticide poisoning: A major global health problem. World Health Stat. Q 1990, 43, 139-144. [PubMed]

45. Foster, S.P.; Harris, M.O. Behavioral manipulation methods for insect pest-management. Ann. Rev. Entomol. 1997, 42, 123-146. [CrossRef] [PubMed]

46. Silverstein, R.M. Pheromones: Background and potential for use in insect pest control. Science 1981, 213, 1326-1332. [CrossRef] [PubMed]

47. Fravel, D.R. Commercialization and implementation of biocontrol. Ann. Rev. Phytopathol. 2005, 43, 337-359. [CrossRef] [PubMed]

48. Riccucci, M.; Lanza, B. Bats and insect pest control: A review. Vespertilio 2014, 17, 161-169.

49. Kasso, M.; Balakrishnan, M. Ecological and economic importance of bats (Order Chiroptera). ISRN Biodivers. 2013, 2013, 1-9. [CrossRef]

50. Cleveland, C.J.; Betke, M.; Federico, P.; Frank, J.D.; Hallman, T.G.; Horn, J.; Lopez, J.D., Jr.; McCracken, G.F.; Medellin, R.A.; Moreno-Valdez, A.; et al. The economic value of pest control services provided by the Brazilian free-tailed bats in south-central Texas. Front. Ecol. Environ. 2006, 4, 238-243. [CrossRef]

51. Federico, P.; Hallam, T.G.; McCracken, G.F.; Purucker, S.T.; Grant, W.E.; Correa-Sandoval, A.N.; Westbrook, J.K.; Medellin, R.A.; Cleveland, C.J.; Sansone, C.G.; et al. Brazilian free-tailed bats as insect pest regulators in transgenic and conventional cotton crops. Ecol. Appl. 2008, 18, 826-837. [CrossRef] [PubMed]

52. Leelapaibul, W.; Bumrungsri, S.; Pattanawiboon, A. Diet of wrinkle-lipped free-tailed bat (Tadarida plicata Buchannan, 1800) in central Thailand: Insectivorous bats potentially act as biological pest control agents. Acta Chiropterol. 2005, 7, 111-119. [CrossRef]

53. Puig-Montserrat, X.; Torre, I.; López-Baucells, A.; Guerrieri, E.; Monti, M.M.; Ràfols-García, R.; Ferrer, X.; Gisbert, D.; Flaquer, C. Pest control service provided by bats in Mediterranean rice paddies: Linking agroecosystems structure to ecological functions. Mamm. Biol. 2015, 80, 237-245. [CrossRef]

54. Malmqvist, E.; Jansson, S.; Zhu, S.; Li, W.; Svanberg, K.; Svanberg, S.; Rydell, J.; Song, Z.; Bood, J.; Brydegaard, M.; et al. The bat-bird-bug battle: Daily flight activity of insects and their predators over a rice field revealed by high-resolution Scheimpflug Lidar. R. Soc. Open Sci. 2018, 5, 172-303. [CrossRef] [PubMed]

55. Kemp, J.; Lopez-Baucells, A.; Rocha, R.; Vangensteen, O.S.; Andriatafika, Z.; Nair, A.; Cabeza, M. Bats as potential suppressors of multiple agricultural pests. A case study from Madagascar. Agric. Ecosyst. Environ. 2019, 269, 88-96. [CrossRef]

56. Wanger, T.C.; Darras, K.; Bumrungsri, S.; Tscharntke, T.; Klein, A.M. Bat pest control contributes to food security in Thailand. Biol. Cons. 2014, 171, 220-223. [CrossRef]

57. Ohkubo, N.; Kisimoto, R. Diurnal periodicity of flight behaviour of the brown planthopper, Nilaparvata lugens STÅL, in the 4th and 5th emergence periods. Jap. J. Appl. Entomol. Zool. 1971, 15, 8-16. [CrossRef] 
58. Nguyen, T.N.; Ruangwiset, A.; Bumrungsri, S. Vertical stratification in foraging activity of Chaerephon plicatus (Molossidae, Chiroptera) in central Thailand. Mamm. Biol. 2019, in press.

59. Srilopan, S.; Bumrungsri, S.; Jantarit, S. The wrinkle-lipped free-tailed bat (Chaerephon plicatus Buchannan, 1800) feeds mainly on brown planthoppers in rice fields of central Thailand. Acta Chiropterol. 2018, 20, 207-219. [CrossRef]

60. Ul Ane, N.; Hussein, M. Diversity of insect pests in major rice growing areas of the world. J. Entomol. Zool. Stud. 2016, 4, 36-41.

61. Preap, V.; Zalucki, M.P.; Jahn, G.C. Brown planthopper outbreaks and management. Cambodian J. Agric. 2006, 7, 17-25.

62. Pathak, M.D. Ecology of rice pests. Ann. Rev. Entomol. 1968, 13, 257-294. [CrossRef]

63. Begum, M.A.; Nur, A.; Haq, M. Abundance and species composition of rice green leafhopper (Hemiptera: Cicadelladae) in different ecosystems. Int. J. Biosci. 2014, 4, 74-79.

64. Singh, B.B.; Singh, R. Major rice insect pests in northeastern UP. Int. J. Life Sci. Biotechn. Pharma Res. 2014, 3, 124-143.

65. Das, A.; Das, S.; Haldar, P. Effect of food plants on the growth rate and survivability of Hieroglyphus banian (Fabricius) (Orthoptera: Acridoidea), a major paddy pest in India. Appl. Entomol. Zool. 2002, 37, $207-212$. [CrossRef]

66. Jagadeesha Kumar, B.D.; Chakravarthy, A.K.; Doddabasappa, B.; Basavaraju, B.S. Biology of the rice gall midge, Orseolia oryzae (Wood-Mason) in southern Karnataka. Karnataka J. Agric. Sci. 2009, 22, 535-537.

67. Malhi, B.S.; Brar, D.S. Biology of yellow stem borer, Scirpophaga incertulas. J. Insect Sci. 1998, 11, $27-129$.

68. Dale, D. Insect Pests of the Rice Plant-Their Biology and Ecology. In Biology and Management of Rice Insects; Heinrichs, E.A., Ed.; IRRI: Los-Banos, Philippines, 1994; pp. 363-485.

69. Fu, X.-W.; Li, C.; Feng, H.-Q.; Liu, Z.-F.; Chapman, J.W.; Reynolds, D.R.; Wu, K.M. Seasonal migration of Cnaphalocrocis medinalis (Lepidoptera: Crambidae) over the Bohai Sea in northern China. Bull. Ent. Res. 2014, 104, 601-609. [CrossRef] [PubMed]

70. Tanwar, R.K.; Prakash, A.; Panda, S.K.; Swain, N.C.; Garg, D.K.; Singh, S.P.; Kumar, S.S.; Bambawale, O.M. Rice Swarming Caterpillar (Spodoptera Mauritia) and its Management Strategies. In Technical Bulletin 24; National Centre for Integrated Pest Management: New Delhi, India, 2010; p. 20.

71. Pennisi, L.A.; Holland, S.M.; Stein, T.V. Achieving bat conservation through tourism. J. Ecotour. 2009, 3, 195-207. [CrossRef]

72. Bagstad, K.J. Toursim value for mexican free-tailed bat viewing. Hum. Dim. Wildl. 2013, 18, 307-311. [CrossRef]

73. Bat Conservation International. Congress Avenue Bridge. Available online: http://www.batcon.org/index. php/our-work/regions/usa-canada/protect-mega-populations/cab-intro (accessed on 25 January 2019).

74. Hosono, T.; Uchida, T.; Suda, C.; Ueno, A.; Nakagawa, T. Salt weathering of sandstone at the Angkor monuments, Cambodia: Identification of the origins of salts using sulfur and strontium isotopes. J. Archaeol. Sci. 2006, 33, 1541-1551. [CrossRef]

75. Feilden, B. Conservation of Historic Buildings, 3rd ed.; Routledge: London, UK, 2007; p. 404.

76. Shahack-Gross, R.; Berna, F.; Karkanas, P.; Weiner, S. Bat guano and preservation of archaeological remains in cave sites. J. Archaeol. Sci. 2004, 31, 1259-1272. [CrossRef]

77. Howard, J. Bats and historic buildings. The importance of making informed decisions. J. Architect. Cons. 2009, 15, 81-100. [CrossRef]

78. Alonso, A.; Irañeta, S.G.; Rodríguez, S.M.; Scavini, L.M.; Rodríguez, S.R. Bat feces as an indoor allergen. J. Investig. Allergol. Clin. Immunol. 1998, 8, 365-369. [PubMed]

79. Bartlett, P.C.; Vonbehren, L.A.; Tewari, R.P.; Martin, R.J.; Eagleton, L.; Isaac, M.J.; Kulkarni, P.S. Bats in the belfry: An outbreak of histoplasmosis. Am. J. Public Health 1982, 72, 1369-1372. [CrossRef] [PubMed]

80. Mitchell-Jones, A.J.; McLeish, A.P. (Eds.) Bat Worker's Manual, 3rd ed.; Joint Nature Conservation Committee: Peterborough, UK, 2004; p. 178.

81. Tupinier, D. La Chauve-Souris et L'homme; L'Harmattan: Paris, France, 1989; p. 218.

82. Tuttle, M.D. Fear of bats and its consequences. J. Bat Res. Cons. 2018, 10, 66-69. [CrossRef]

83. Parashar, S. Religious Belief and Ethical Values of Rigveda: A Book on Rigveda, 1st ed.; Notion Press: Chennai, India, 2018; p. 276. 
84. Rydell, J.; Eklöf, J.; Sánchez-Navarro, S. Age of enlightenment: Long-term effects of outdoor aesthetic lights on bats in churches. R. Soc. Open Sci. 2017, 4, 1077. [CrossRef] [PubMed]

85. Zeale, M.R.K.; Bennitt, E.; Newson, S.; Packman, C.; Browne, W.J.; Harris, S.; Jones, G.; Stone, E.L. Mitigating the impact of bats in historic churches: The response of Natterer's bats Myotis nattereri to artificial roosts and deterrence. PLoS ONE 2016, 11, e0146782. [CrossRef]

86. Furey, N.; Racey, P.; Ith, S.; Touch, V.; Cappelle, J. Reproductive ecology of wrinkle-lipped free-tailed bats Chaerephon plicatus (Buchannan, 1800) in relation to guano production in Cambodia. Diversity (Pnom Penh) 2018, 10, 91. [CrossRef]

87. Thies, M.L.; Thies, K.; McBee, K. Organochlorine pesticide accumulation and genotoxicity in Mexican free-tailed bats from Oklahoma and New Mexico. Arch. Environ. Contam. Toxicol. 1996, 30, 178-187. [CrossRef] [PubMed]

88. Rydell, J.; Speakman, J.R. Evolution of nocturnality in bats: Potential competitors and predators during their early history. Biol. J. Lin. Soc. 1995, 54, 183-191. [CrossRef]

89. Voigt, C.C.; Azam, C.; Dekker, J.; Ferguson, J.; Fritze, M.; Gazaryan, S.; Hölker, F.; Jones, G.; Leader, N.; Lewanzik, D.; et al. Guidelines for Consideration of Bats in Outdoor Lighting Projects; UNEP: Bonn, Germany, $2018 ;$ p. 67.

(C) 2019 by the authors. Licensee MDPI, Basel, Switzerland. This article is an open access article distributed under the terms and conditions of the Creative Commons Attribution (CC BY) license (http://creativecommons.org/licenses/by/4.0/). 